\title{
A DITADURA MILITAR NO BRASIL E O TEATRO: MEMÓRIA E RESISTÊNCIA DA CLASSE ARTÍSTICA ${ }^{1}$
}

\author{
César Alessandro Figueiredo ${ }^{2}$
}

\begin{abstract}
Resumo
O presente artigo como objetivo principal analisar o protagonismo do teatro e, principalmente, da classe artística, no cenário político brasileiro na luta contra a ditadura militar brasileira. Conforme realçado ao longo do texto, a ditadura militar no Brasil durou de 1964 a 1985, ou seja, 21 anos em que houveram sérios cerceamentos dos direitos políticos dos brasileiros. Construímos como hipótese, que nesta conjuntura política adversa a classe artística levantou-se capitaneando, em conjunto com outras forças políticas, a luta contra o regime militar. Para a consecução do artigo em tela, utilizamos de uma pesquisa qualitativa através da análise de conteúdo dos elementos mais significativos, tanto da bibliografia que pudessem aludir ao período quanto de material fílmico que contribuísse para a pesquisa realizada. Finalizando, concluímos que, com certeza, o teatro foi uma grande trincheira de luta contra o regime ditatorial e os palcos serviram de verdadeiras trincheiras para a classe artística servindo de porta voz para a população reverberar os seus dramas.
\end{abstract}

Palavras-Chaves: Ditadura militar, resistência artística, teatro, redemocratização.

\begin{abstract}
This article is meant to examine the role of theater and especially the artistic community in the Brazilian political scene in the fight against the Brazilian military dictatorship. As highlighted throughout the text, the military dictatorship in Brazil lasted from 1964 to 1985, or 21 years in which there were serious fenced off political rights of Brazilians. We built as a hypothesis, that this adverse political climate the artistic community rose captaining, together with other political forces, the struggle against the military regime. To achieve the article in question, we used a qualitative research through content analysis of the most significant elements of both the bibliography that could allude to the period as a film material that contributes to the survey. Finally, we conclude that, of course, the theater was a big trench of struggle against the dictatorial regime and the stage served as a true trenches for the artistic community serving as a spokesman for the population reverberate their dramas.
\end{abstract}

Keywords: Military dictatorship, artistic resistance, theater, democratizatio

\section{Resumen}

Este artículo tiene la intención de examinar el papel del teatro y especialmente la comunidad artística en la escena política brasileña en la lucha contra la dictadura militar brasileña. Como se destaca en el texto, la dictadura militar en Brasil duró 1964 hasta 1985, o 21 años en los que había serios vallado derechos políticos de los brasileños. Construimos como hipótesis, que este clima político adverso a la comunidad artística capitaneando subió, junto con otras fuerzas políticas, la lucha contra el régimen militar. Para conseguir el artículo en cuestión, se utilizó una investigación cualitativa mediante el análisis de contenido de los elementos más importantes tanto de la bibliografía que podría aludir al período como material de película que contribuye a la encuesta. Finalmente, llegamos a la conclusión de que, por supuesto, el teatro fue una gran trinchera de la lucha contra el régimen dictatorial y la etapa sirvió como un verdadero zanjas para la comunidad artística que actúa como portavoz de la población reverberan sus dramas.

Palabras-Clave: dictadura militar, resistencia artística, el teatro, la democratización

\footnotetext{
${ }^{1}$ DOI deste artigo: $10.5380 /$ recp.v6i2.44240.

2 Prof. ${ }^{\circ}$ Adjunto da Universidade Federal de Tocantins (UFT) e coordenador do curso de Ciências Sociais. Trabalha com a linha de pesquisa em Memória Política, Ditadura Militar e Partidos Políticos desenvolvendo pesquisa sobre a Guerrilha do Araguaia e reparações do Estado. E-mail: cesarpolitika@uft.edu.br.
} 


\section{INTRODUÇÃO}

A ditadura militar no Brasil, sem dúvida, foi um dos fatos mais marcantes na política brasileira, pois foi o evento que desmanchou o cenário multipartidário anterior ao Golpe Militar, em 1964, assim como, moldou o cenário institucional do Brasil após a redemocratização, em 1985. Ou seja, foi um percurso de 21 anos de repressão e cerceamento das liberdades políticas, período este que trouxe severos reflexos para a qualidade da democracia no Brasil, em face do longuíssimo período de ruptura da ordem institucional legal.

Além da ruptura da ordem legal, houve a falta dos direitos civis e políticos para a população, uma vez que mesmo com eleições regulares ocorreu extinção dos partidos anteriores ao Golpe. A partir de 1966, é editado o Ato Institucional nº 2 (AI-2), que extinguia os partidos políticos e findava com a dinâmica do multipartidarismo no Brasil. Deste momento em diante, a nação brasileira contava com apenas dois partidos: 1) Aliança Renovadora Nacional (ARENA), partido de apoio à ditadura; e, 2) Movimento Democrático Nacional (MDB), partido de oposição consentida à ditadura militar. No entanto, devemos realçar que embora mantendo eleições regulares, que tentavam demonstrar certa "normalidade" política, havia uma ditadura militar que foi ao longo do período (21 anos) se tornando cada vez mais opressora, principalmente, a partir da implementação do Ato Institucional no 5 (AI-5), em 1968: o regime fechava totalmente e sobravam poucos lócus à cidadania, à política e, inclusive, à cultura.

No tocante a cultura essa foi um dos espaços de grande resistência contra a ditadura militar, com a classe artística desempenhando um papel protagonista durante todo o período ditatorial. Destacamos neste embate, principalmente o teatro, uma vez que a televisão, nos anos 60, ainda estava no seu nascedouro ${ }^{3}$. Portando, os palcos tornaram-se verdadeiras trincheiras de resistência e embate na luta contra o regime de exceção. Diversas peças foram censuradas, assim como, muitos atores e diretores sofrerem os revezes da prisão e do arbítrio, em virtude de serem protagonistas além dos palcos, da luta de fato contra ditadura. O discurso da classe artística neste período em tela conjugava além da representação de cena, também, a dor, a luta, o sofrimento e a resistência contra o arbítrio militar.

\footnotetext{
${ }^{3}$ A primeira televisão do Brasil foi inaugurada em 1950, a TV Tupi. Portanto no início dos anos 60 ainda havia poucos canais de televisão e não integrados em rede nacionais. $O$ rádio ainda era o principal veiculo de comunicação mais institucionalizado e com isso mais censurado, quanto ao teatro por ter um caráter mais autoral representava o ambiente natural para a contestação
} 
Em face do exposto, esse artigo possui como objetivo principal examinar a importância do teatro na resistência contra a ditadura militar, destacando as peças e grupos de teatros, bem como, a participação ativa da classe artística neste período tão conturbado da história do Brasil como um dos personagens principais na luta conta a ditadura militar. Com o intuito de trabalharmos com um período tão amplo e conturbado, delimitaremos o este artigo nas seguintes fases: 1) o teatro de resistência: limiar do golpe até a instituição do AI5; 2) o teatro sob coação: após o AI-5 até os primeiros ventos liberalizantes no final da década de 70; e, 3) o teatro da denúncia: do final dos anos 70 e a redemocratização do Brasil. Para tanto, procuraremos construir o diálogo das artes no Brasil inserindo dentro da moldura política do período com o intuito de contextualizá-lo historicamente, ou seja, colocando o teatro e a classe artística face a face com o processo histórico de resistência democrática a ser tratado em tela.

\section{O TEATRO DA RESISTÊNCIA: LUTAR E RESISTIR - ESTE É O LEMA.}

O cenário político do início dos anos 60 era extremamente complexo, com uma moldura política incerta, tanto no espectro nacional quanto internacional. Lembramos que o mundo se dividia bipolarmente entre a esquerda e a direita, mais precisamente entre o Leste europeu comunista e Ocidente capitalista. Da mesma forma, no Brasil tínhamos no início dos anos 60 o governo de João Goulart, que era vice de Janio Quadros e assumiu o governo com a vacância do cargo de Presidente. Jango assumiu com severas reservas da corporação militar, em face das suas ligações com a plêiade do trabalhismo. Realçamos que desde o momento da posse de Jango a corporação em conluio com a elite política e eclesial oponente tentou derrubá-lo, em virtude que este presidente tentou colocar em xeque o status quo com a edição das suas Reformas de Bases.

Estas Reformas eram um conjunto de medidas que visavam transformar o país, através de medidas progressistas dentro do marco legal. Em síntese, era uma série de medida de caráter paliativo, que transformava o sistema bancário, eleitoral e, principalmente, agrário com a tentativa de uma reforma agrária. Mudanças demais no cenário político e que incomodavam muito a corporação militar em face dos desvios esquerdizantes de um presidente ligado ao trabalhismo com o apoio dos comunistas e do baixo escalão da corporação militar: o cenário político se fechava (FIGUEIREDO, 1993).

Neste ínterim a sociedade civil se dividia também, entre os que apoiavam as Reformas de Base e os que eram radicalmente contrários. No quadro dos que apoiavam havia 
um amplo leque de forças progressistas, mas sem uma densidade política que pudessem sustentar a radicalidade das mudanças propostas por João Goulart, entre estes destacamos, por exemplo, o Partido Comunista Brasileiro (PCB), os trabalhistas ligados ao Partido Trabalhista Brasileiro (PTB), a União Nacional dos Estudantes (UNE), ou seja, um leque amplo mais sem densidade política. Dentro deste campo progressista encontrava-se, também, a classe artística dando suporte a este elenco de Reforma de Base proposto por Goulart, destacamos o caso exemplar do Centro Popular de Cultura (CPC) criado em 1961, ligado a União Nacional dos estudantes (UNE) e capitaneada pelo eminente teatrólogo Oduvaldo Viana Filho4.

Grosso modo, podemos dizer que havia um conjunto de forças progressistas dispostas a construir um novo Brasil, em que a cultura tinha uma centralidade. Em síntese, vislumbrava-se um novo Brasil, tínhamos a Bossa Nova, o nascimento do Cinema Novo, assim como um novo teatro popular com o intuito de passar uma nova mensagem (RIDENTI, 2000). O CPC teve grande expressão no Rio de Janeiro, em virtude da sede da UNE. Em São Paulo, um teatro similar exercia grande atração pelo ineditismo das suas peças, era o Teatro de Arena em São Paulo, com a emblemática peça de Gianfrancesco Guarnieri, Eles Não Usam Black-Tie (1958), sendo interpretado no Rio de Janeiro e São Paulo respectivamente pelo CPC e Arena.

Realçamos, neste contexto, o engajamento da classe artista, bem como, a adesão da mesma a partidos de esquerdas, destacamos o caso do PCB, maior partido de esquerda do período $^{5}$. Ou seja, era quase condição sine qua non para estar integrado na classe artística, também, ser simpatizante do PCB, a organização que galvanizava o grosso da militância de esquerda do período. Conforme pode ser visto exemplarmente no argumento da peça Eles Não Usam Black-Tie, a qual retratava um clímax de greve entre patrões e empregado, dito de outra maneira, a luta de classes tão propalada pela esquerda. Ou seja, era uma peça teatral de características bem marcantes do período bipolar (esquerda e direita), sendo a classe trabalhadora a grande protagonista da luta.

No tocante a genealogia do Novo Teatro Brasileiro surgido nos anos 50 tinha-se o Teatro Popular do Estudante (TPE), que funde-se em 1956 ao Teatro de Arena que já existia desde 1956. Já no início dos anos 60 o Arena vai cumprir uma temporada de sucesso no Rio

\footnotetext{
${ }^{4}$ Oduvaldo Vianna Filho, também conhecido como Vianinha (São Paulo, 4 de julho de 1936 — Rio de Janeiro, 16 de julho de 1974) foi um dramaturgo, ator e diretor de teatro e televisão brasileiro. In.: PATRIOTA, Rosângela. Vianinha: um dramaturgo no coração de seu tempo. São Paulo, Hucitec, 1999.

${ }^{5}$ No início dos anos 60 novas organizações surgem não egressas do velho tronco comunista, como a Política Operária (POLOP), fundada em 1961; e, a AP (ação Popular), fundada em 1962 (AARÃO REIS FILHO, 1990).
} 
de Janeiro (ainda a capital cultural mais importante no Brasil). Nesse clímax político e cultural uma parte do Arena resolve ficar no Rio para fundar o CPC, segundo as diretrizes do birô político do PCB. Neste enfoque visando juntar cultura e consciência popular no nascimento do novo homem e no porvir de uma nova sociedade socialista, levavam o teatro para as favelas e para as portas de fábricas para fomentar o nascimento desse homem novo (IDEM, 2000).

Nesta conjuntura bipolar extremamente dialético, conforme enfatizado, o governo Goulart se viu acossado pela corporação militar que logrou uma manobra política com o apoio do alto clero e da elite brasileira. Assim sendo, em 31 de Março encerra-se mais um ciclo democrático no Brasil e começa uma longa ditadura militar (DREIFUSS, 1981). No começo acreditava-se que a ditadura não iria durar tanto, mas de acordo com o tempo transcorrido e com a edição dos Atos Institucionais, verificou-se que a ditadura veio realmente para ficar, pois começou as medidas repressivas contra quem ousassem desafiar o regime vigente. Obviamente, que os primeiros a sofrerem os arbítrios foram a plêiade do trabalhismo, os comunistas, assim como, a UNE e o seu elenco de apoiadores como o CPC: a partir deste momento a classe artística começou a ficar entrincheirada, a arte virou resistência política - era preciso resistir e denunciar.

O cenário político pós-golpe trouxe inúmeros dissabores para todo o elenco de atores que visavam construir um novo Brasil influenciado pelas políticas implementadas nas Reformas de Base. O Brasil que surgia era um país dirigido pela corporação militar que agia efetivamente com o exercício de cercear e punir quem ousasse opor-se ao regime vigente, podemos dizer que era uma briga extremamente desigual, porém empunhada vigorosamente por um conjunto de atores políticos extremamente ecléticos: militantes de esquerda, estudantes, artistas e novos personagens que entravam em cena no pós-64. Destacamos que a classe artística desde o primeiro momento do Golpe mostrou um papel extremamente ativo na defesa das liberdades civis e nas denúncias contra a ditadura: os palcos dos teatros tornaram-se cenário para plenárias entre os ativistas no combate ao regime opressor, porém era a briga do rochedo contra o mar.

Com o cerceamento da UNE e com o fim precoce do CPC, o grosso dos ativistas da classe teatral que compunham o CPC migraram para o recém fundado grupo Opinião. Neste processo no pós-64 o show Opinião dirigido por Augusto Boal ${ }^{6}$, com a proposta de um musical tendo à frente, numa primeira temporada a cantora Nara Leão, secundada por Zé

\footnotetext{
${ }^{6}$ Augusto Pinto Boal (Rio de Janeiro, 16 de março de 1931 - Rio de Janeiro, 2 de maio de 2009) foi diretor de teatro, dramaturgo e ensaísta brasileiro, uma das grandes figuras do teatro contemporâneo internacional.
} 
Kéti e João do Vale, representava respectivamente a menina da Zona Sul carioca, o negro malandro do morro e o sujeito do campo. A canção emblemática cantada por Nara Leão dizia nos versos: Podem me prender, podem me bater / Podem até deixar-me sem comer / Que eu não mudo de opinião. A continuidade de sucesso no show se dá com a saída de Nara Leão sendo substituída de maneira bombástica pela presença da Maria Bethania que estreava no Rio de Janeiro nesse musical de estrondoso sucesso - a menina da zona sul é substituída pela menina do nordeste que cantava as mazelas do seu povo: a síntese do Brasil denunciando a ditadura militar através de um musical, o público ia ao delírio numa catarse coletiva (RIDENTI, 2000).

Não obstante todo o cerceamento um novo teatro renascia pós 1964, surgia um teatro extremamente combativo que ficava par a par com a ordem vigente: era guerrilha teatral. Enfatizamos que com o cerceamento das instituições democráticas pela corporação militar os agentes políticos começaram a gestar novas estratégias para romper a opressão, a luta armada e o exemplo da Revolução Cubana serviam como inspiração que legitimava as organizações de esquerda; neste período, também, o PCB começava a perder a hegemonia surgindo uma Nova Esquerda egressa do velho tronco comunista, disposta a pegar em armas e confrontando com o pacifismo do PCB. Assim, em meados dos anos 60 começaram a surgir as primeiras ações armadas capitaneadas por estas novas organizações (AARÃO REIS FILHO, 1990; GORENDER, 1987). Quanto à influência da Revolução Cubana no pensamento político Latino americano, Emir Sader (1991) explicita-os nos seguintes tópicos:

1) Em primeiro lugar, ela representou a atualização da revolução para esquerda brasileira, um fenômeno até então corporificado pela revolução soviética, com todas as suas implicações;

2) Outro elemento que passou a caracterizar a Revolução Cubana foi a legitimação da heterodoxia política e ideológica;

3) O anti-imperialismo e o anticapitalismo se articulam na Revolução Cubana na medida da integração estrutural da burguesia cubana com os EUA e com o imediato reconhecimento desse país como potência imperialista e capitalista;

4) A estratégia de poder que marcou a revolução Cubana foi a guerra de guerrilha baseada no campo, a partir de onde foi se organizando um exército revolucionário que, posteriormente, foi ocupando geograficamente o país em direção à capital;

5) Desde o seu início, a revolução Cubana incorporou a dimensão da solidariedade internacional como um dos aspectos essenciais e sua formação ideológica e ação política;

6) Outra face desse aspecto ideológico estava reservado para o plano moral: a ética da dedicação revolucionária, o sacrifício da própria vida, a militância revolucionária identificada com a sua própria vida;

7) Outro aspecto dessa mesma característica marcante da revolução Cubana é a ênfase no papel da vanguarda e, em geral, nos chamados aspectos subjetivos dos processos históricos (IDEM, p. 167-171). 
O teatro não ficara de fora de todo esse movimento e contextualização política, conforme enfatizando, a luta armada saia das ruas e invadia os palcos servindo de exemplo e propaganda de luta. Destaca-se neste período o diretor José Celso Martinez Corrêa a frente do Teatro Oficina com peças emblemáticas como O rei da Vela (1967), enfatizando a dicotomia da luta de classe, caindo perfeitamente para a realidade de luta. O de teatro de Arena continuava extremamente forte com a direção de Augusto Boal, com os musicais como Arena Conta Zumbi (1965), enfatizando justamente a derrota do Quilombo do Palmares numa clara alusão a derrota da esquerda em 1964. Posteriormente, encenam o espetáculo Arena Conta Tirandentes, recriando através de figuras paradigmáticas da história do Brasil o contexto política, buscando trazer a mensagem da luta dialética contínua entre os opressores e oprimidos, identificando-se com a proposta guerrilheira (RIDENTI, 2000, p. 157). Ou seja, eram peças emblemáticas que mostravam toda a criatividade de classe artística para romper com liames de uma ditadura que fustigava e não dava sinais de abrandamento. No ano de 1968, Oduvaldo Viana Filha constrói o argumento de uma peça síntese do período, buscando dialogar com todos os atores, tendências, personagens e partidos do cenário latino-americano através da peça Papa Highirte (1968):

[...] a construção da temática de Papa Highirte teve como pressuposto a necessidade de pensar a própria experiência latino-americana. Sob a égide da ordem e da modernização, a prática de poder dos governos militares (ou governos sustentados por eles) utilizou procedimentos autoritários. A peça revelou ainda alguns caminhos percorridos por aqueles que atuavam no campo da esquerda, sobretudo considerando que o advento da Revolução Cubana, a vinda de Ernesto "Che" Guevara para a América Latina e a teoria do "foquismo" de Régis Debray suscitaram atuações que se tornaram uma constante. Ao lado destas experiências e em oposição a elas, a interpretação dos Partidos Comunistas conclamava à resistência e à necessidade de consolidar a acumulação de forças para a transformação democrática, que deveria exorcizar os fantasmas da opressão: o populismo, os governos militares, o alto grau de exploração e pauperização das sociedades sul-americanas (PATRIOTA, 1999, p. 128$9)$.

Dando continuidade as peças paradigmáticas do período no mítico ano de 1968 é encenada Roda Viva (1968), de autoria de Chico Buarque e dirigida por José Celso Martinez Corrêa. O espetáculo conta a história de um cantor que é tragado pela nascente industrial cultural da época; no entanto, a forma agressiva de expor chocou o público com severas reações da corporação militar. Em todas as apresentações o elenco sofria ameaças de invasão por parte do Comando de Caça aos Comunistas (CCC), pois a julgavam extremamente ofensiva (VENTURA, 1968). A peça extreia no Rio de Janeiro, no início do ano, e cumpre 
uma agenda de sucesso até meados de Junho, quando o teatro é invadido e os atores são espancados pelo CCC. Zuenir Ventura em seu livro, 1968: o ano que não terminou (1988), recriou o clímax da tensão que vivia os atores na peça sofrendo ameaças de bombas e coações. Tensão em grau máximo ocorre quando houve a temporada da peça em Porto Alegre, no RS, em que os atores principais da peça foram seqüestrados e levados para um local ermo sob ameaça de morte, depois desse episódio decidiram encerram a peça: o sinal defintivamente se fechara, pois os palcos se tornaram objeto da policia política.

A classe artística atônica começaria a ensair novas formas de resistência, inclusive, apoiando de fato as emergente ações armadas dos grupos guerrilheiros inciadas em 1968, pois os palcos começaram a ser seriamente cercerados por censura rígida de uma ditadura militar implacável. A censura restringia e ameaçava o teatro, pois antes de estrearem uma peça tinham que se apresentar ao censor, portanto, no final do mítico ano de 68 começava a minguar os espaço de resistência nos teatros. Soma-se ao quadro de opressão, em 13 de dezembro de 1968, era editado o Ato Insitucional no -5, (AI-5) que entre outras medidas podia prender qualquer pessoa suspeita, ou seja, era a ditadura às claras. Neste período se institucionalizava o sequestro, a prisão e a tortura a todos os oponentes do regime militar: a noite escura se impôs e as luzes da ribalta teimavam em permancer acesa, mesmo que a custas de mortes e prisões.

\section{TEATRO SOB COAÇÃO: DENTRO DA NOITE ESCURA EMERGE O TEATRO NAS SOMBRAS}

A partir de 1968 surgem novas organizações políticas egressas do tronco do velho PCB, com o intuito de romper com o imobilismo pacifista pecebista. Destaco pelo relevo das ações que efetivaram na luta armada, a Aliança Libertado Nacional (ALN), em São Paulo; e, no Rio de Janeiro, o Movimento Revolucionário Oito de Outubro (MR-8). Ainda, tornase importante ressaltar que, além dessas organizações egressas do PCB, surgiram diversas organizações armadas de cunho militaristas como desdobramentos das fissuras no seio das outras organizações de esquerdas que surgiram no início dos anos 60. Destacamos entre outras, a POLOP, que deu origem ao Comando de Libertação Nacional (COLINA); e, a Vanguarda Armada Revolucionária (VPR), de caráter bem mais militar, que posteriormente, em 1969, se unificaram fundindo-se temporariamente como Vanguarda Amarada Revolucionária-Palmares (VAR-Palmares). 
Torna-se importante este registro dessas organizações pois muito dos remanescentes da resistência da classe artística, conforme realçado, passaram auxiliar logisticamente nas ações armadas, dando, por exemplo, dinheiro de bilheterias para apoio essas organizações e seus militantes na clandestinidade (RIDENTI, 2000; SIRKIS, 1984). Além do apoio logístico, muitos atores integraram esses grupos de resistência armada, destacamos, por exemplo, a atriz Bete Mendes, que integrou a Vanguarda Armada Revolucionária - Palmares (VARPalmares), e que por suas ações políticas foi presa e torturada no início dos anos 70, mesmo sendo uma figura pública e estando no ar numa novela de enorme sucesso da TV Record. Ou seja,a ditadura não poupava ninguém; mesmo starlets do primeiro time da televisão brasileira no horário nobre (PATARRA, 1992)

Um dos casos paradigmáticos é a da diretora de teatro e professora universitária Heleny Telles Guariba, personagem de destaque nas artes do final dos anos 60 e que trabalhava no teatro de Arena com Augusto Boal. Heleny adere a Vanguarda Popular Revolucionária (VPR). Identificada pelas forças da repressão no final de 69 é presa e torturada, conseguiu sair da cadeia no início de 71 e retoma a militância sob as hostes da VPR. Porém, novamente é localizada pelas forças repressivas e torna-se um dos desaparecidos políticos no Brasil (IDEM, 1992; CARVALHO, 1998). Em síntese, sobrava pouco espaço para resistência; podia-se fazer muito pouco, sobrava a luta desigual de combate a ditadura através da luta armada: a noite escura se impôs.

Destaco também o caso da consagrada atriz internacional Norma Benguell, que depois de tantas prisões e invasões do teatro durante a apresentação de suas peças precisou se exilar após a sua companheira e diretora da sua peça ser presa e torturada. Ou seja, era extremamente complicado o confronto de ideias, ainda mais para Norma Benguel aliada ativa das organizações de esquerda armada. Quanto a Augusto Boal e José Celso Martinez Correa, estes também são encarcerados e vão para a prisão: após a libertação são impelidos a ir para o exílio para continuar vivos, pois a ditadura impossibilitou tanto o o exercício de seus trabalhos, quanto a garantia deles manterem-se vivos.

Grosso modo, devemos enfatizar que a ditadura pretendia além de destruir a vida das pessoas, também, destruir a carreira de muitos atores, pois como continuar sendo ator em outros países e contornar o idioma e o sotaque (com exceção de Norma Benguell que conseguiu fazer carreira internacional). A carreira muitas vezez ficava em suspensão, pois muitos não conseguiam dar continuidade as suas atividades artística; se antes tínhamos o teatro na trincheira, neste momento o teatro precisava escontrar caminhos para fugir da pesada mão ditadura militar. O número de personagens da classe artítica que adere, de fato, 
ou apoiam as ações dos grupos armados é muito grande, seja atores, diretores, cenográfos: a classe artística não se furtou do seu papel na luta contra a ditadura militar. Segundo Marcelo Ridenti em seu livro, Em busca do povo brasileiro: artistas da revolução, do CPC à era da tv (2000), enfatiza que no Tiradentes, principal presídio da ditadura, havia alas de presos tanto das organizações armadas quanto da classe artística; e que estes mesmo presos pemaneciam na militância e tentavam continuar minimamente o seu ofício de artes através dos trabalhos laborais internos e oficinas dentro do presídio.

O período da luta armada no Brasil dura de 1968 até 1975, ou seja, desde o seu início até o seu completo aniquilamento, seja por prisão ou assassinato dos oponentes ${ }^{7}$. A classe artística precisava se refazer e conjugar outros verbos era necessário um novo teatro, assim como uma nova forma de resistência aos regime vigente. Nas brechas da repressão, em face de tanta opressão, começou a surgir conjuntamente um contracultura que visava romper com o status quo, surge um cenário mais underground, misturando com elementos da cultura bippie emergente. Neste percurso e com a necessidade sufocante de falarem e de passarem mensagens "cifradas" de resistência surgem novos grupos alternativos em conjunto com o universo bippie politizado.

Em 1970, o cenário das artes no Brasil é impactado com a peça Hair, homônima do musical americano. A peça retrata o mundo bippie que se descortina no final dos anos $60 \mathrm{e}$ início dos anos 70, o grande clímax da peça era o seus final com todo o elenco nu no palco: grande impacto visual ao mesmo tempo que havia uma ditadura militar tão feroz. Ou seja, ao mesmo tempo que a ditadura aniquilava; não obstante em suas brechas a classe artística conseguia com muita luta passar peças de teatro que buscavam elementos dentro do burlesco e do deboche, e assim conseguia burlar a ditadura vigente. Conforme realçado, passavam por dentro das brechas da ditadura mensagem para denunciar a realidade, em síntese, as mensagens eram cifradas para tentar camuflar e tentar romper com a cruel censura e repressão, tanto no teatro quanto nas músicas (ARAUJO, 2003).

No rol dos vários grupos que surgiram neste período, destacamos a emergência de Asdrúbal Trouxe o Trambone, grupo carioca que buscava trazer humor escrachado e inteligente, capitaneado pelos atores Regina Casé e Luiz Fernando Guimarães, fazendo escola no teatro a partir dos anos 70. Destacavam-se por uma crítica de costumes, com uma abordagem

\footnotetext{
7 Consideramos o período da luta armada iniciada no ano de $1968 \mathrm{com}$ as primeiras ações armadas de expropriações de bancos para arrecadar fundos para as organizações guerrilheiras até o ano de 1975, após o fim da Guerrilha do Araguaia no norte do Tocantins e sul do Pará promovido pelo PCdoB. Ver in.: FIGUEIREDO, César Alessandro Sagrillo. O Impacto da crise do socialismo nos partidos comunistas no Brasil. Tese de Doutorado em Ciências Políticas. Universidade Federal do Rio Grande do Sul, 2013.
} 
política leve e subliminar que burlava qualquer forma de censura da ditadura militar. A sua arma política era um humor debochado que provocava, mas não assustava, destacamos no elenco de suas apresentação a famosa peça Trate-me Leão, criação coletiva do grupo de 1977.

Ainda, destacamos entre os grupos teatrais da contracultura, no mesmo porte, o Dzi Croquette, grupo teatral liderado pelo coreógrafo e diretor Lenie Dale, que a frente de um grupo de rapazes faziam humor, dançavam e interpretavam, vestidos tanto de homens quanto de mulheres, em plena ditadura: deboche puro e ousadia no grau máximo. Obviamente, que para este segundo grupo a repressão se abateu com força pela censura, pois era inadmíssivel um grupo de homens romperem com o paradigma da masculinidade hegêmonica. A despeito da repressão e mesmo com o cerceamento feroz da censura, o grupo conseguia burlar inteligentemente os censores e fez história no eixo Rio-São Paulo. Dando prosseguimento ao seu sucesso; deram as costas para a ditadura e foram se apresentar na Europa, fazendo, realmente grande sensação no Velho Mundo: era a vitória do talento do autêntico do teatro brasileiro contra a homofobia do regime militar ${ }^{8}$.

Porém, nem só escracho e contracultura vivia a cena da teatral, pois os grupos de teatros se multiplicavam através de um teatro experimental, diversos grupos com nomes enfáticos, por exemplo: Renovação, Revolução, Viração, em síntese, nomes que pudessem enfatizar a continuidade de um teatro engajado e popular dos anos 60 , ou seja, herdeiros legítimos do "velho" teatrão do Arena, Opinião e Oficina. Não raro esses grupos subiam aos morros e as favelas do Rio de Janeiro, ou iam para a perifeira dos grandes centros urbanos propondo um teatro engajado e de esclarecimento político da população carente. Sendo que, como era de se esperar toda a ação tinha a sua reação, muitas vezes todo o grupo era preso pela polícia política e, obviamente, todos iam para a tortura, pois ousavam passar a consciência política através da artes (RIDENTI, 2000).

Além dos grupos alternativo o "velho" teatrão resistia, assim como a política brasileira, mesmo asfixiada tinha os seus rasgos de vitórias parciais. Como marco temporal registramos que, em 1974, mantendo o calendário regular eleitoral ocorre as eleições para deputados federais, deputados estaduais e senadores, realçamos que não havia eleição para governador e presidente, portanto, a eleições para senadores assumiam o tônus de uma eleição majoritária (FIGUEIREDO, 2009; FIGUEIREDO, 2013). Neste processo eleitoral a oposição (MDB) consegue conquistar importantes vitórias no sul e sudeste, fato este que faz mudar consideravelmente o quadro político, sublinharmos que eram vitórias parciais e

\footnotetext{
8 Sobre o Dzi Croquete para maiores informações assistir ao premiado documentário de Tatiana Issa (2009).
} In.: http:/ / www.youtube.com/watch?v=rgy8fXEqw98. Assistido em 04/07/2014. 
regionais; sendo que, a ditadura militar aceitou parcalmente essas derrotas. Não obstante, essas vitórias eram a senha que a sociedade civil e organizações de esquerda precisavam para crer numa possível liberalização do regime militar. Este é um fato muito importante, pois para analisarmos os reflexos do difícil período político nas artes, necessariamente precisamos estar cientes dos avanços e recuos, tanto da ditadura militar quanto da sociedade civil organizada, neste sentido enfatizamos que o estado da arte no Brasil sofria os reflexos de todo esse conjunto extremamente dialético que vivia a sociedade brasileira no tocante ao quadro político.

Neste percurso, conforme realçado, ao mesmo tempo que a corporação liberalizava com o intuito de demonstrar que havia uma ditadura militar diferenciada das outras da Cone Sul, pois havia eleições regulares; por outro lado, seletivamente o regime militar continuava prendendo, torturando, assassinando e ocultando os corpos, ou seja, uma ditadura tal e qual qualquer outra da América Latina. Torna-se importante esse registro, o caráter seletivo da ditadura militar, pois escolhia os seus oponentes que deveria sofrer os arbítrios da corporação militar (assassinados) (IDEM, 2009 e 2013). Obviamente, que a classe artística pela sua visibilidade tornava extremamente visada, justamente pela capacidade de propoganda das suas peças de teatro contra a ditadura militar. O crivo da censura era extremalmente implacável, muitos atores e diretores continuavam tendo que se exilar, a ditadura dava brechas de liberdade mas continuava fustigando os seus inimigos escolhidos.

Paulatinamente o teatro voltava a encenar peças de grande comoção com a realidade brasileira, não raro muitas encenações burlavam a censura e em cena aberta - quando não havia polícial infiltrado e censores - davam espaços para os espectadores se manifestarem brandando: onde está o meu filho que se encontra desaparecido? O que aconteceu com o meu marido que está há meses presos e eu ainda não consegui visitá-lo? Era o teatro como porta voz da luta incassável pela redemocratização, tornando-se representante e palanque natural da população que não tinha espaço para se manifestar. No entanto, devemos registrar que eram brechas, ou seja, a cultura da resistência subterrânea nas frestas do regime mas que serviam como difusor do clamor coletivo dos pais e mães engajadas que sofriam na busca de seus filhos desaparecidos, muitas vezes dando bilhetes para artistas para divulgar nos meios de comunicação que os seus filhos se encontravam presos políticos (AUTRAN, s/d; CARVALHO, 1998).

No elenco das grandes damas do teatro que continuavam a sua luta enfatizamos Bibi Ferreira, com peças de destaques ao longo dos anos 70. Como por exemplo, em 1977, $A$ Gota D'água, mais um sucesso teatral musicado por Chico Buarque e ideia originalmente de 
Oduvaldo Viana Filho, sendo dirigida pelo diretor italiano Gianni Ratto. A peça retratava a trágica peça grega Médeia trasmutada para uma favela carioca, conjugando a vida cotidiana e costumes com a genialidade de Chico Buarque e a direção primorosa de Vianinha. Nesta encenação ao retratar o morro e o popular, mostrava com toda a densidade a pobreza e o desemprego, contrastando e colocando em xeque, portanto, o aludido Milagre Econômico Brasileiro da década de 70 tão propalado pela ditadura militar'. Conforme já realçado, quanto a Oduvaldo Viana Filho, sua genialidade vinha desde o CPC da UNE, sem abrir mão continava a imprimir um teatro extremamente engajado ao longo dos anos 70 (PATRIOTA, 1999).

Em 1978, ainda sob a condução de Chico Buarque é encenado também mais um musical, $A$ Ópera do Malandro. A peça retrata a velha Lapa dos anos 40, porém com todas as críticas de costumes facilmente legível para o período em tela. Esta peça, assim como as outras do período, fora extremamente censurada tendo vários cortes, ainda mais em virtude do seu diretor, José Celso Martinez Corrêa, inimigo da ditadura e ex preso político. Juntavase, portanto, a genialidade do autor e compositor, com a marca de contestação de Zé Celso. Grandes talentos que juntos se uniram através de um recorte temporal a partir da Lapa do passado para discutir a realidade presente daquele momento no Brasil.

Neste interim, a sociedade civil continuava a fustigar a ditadura, em 1978 novamente era marcado uma eleição geral no Brasil, neste momento as eleições atingiram um climax de um caráter plebiscitário: pró e contra a ditadura. A ditadura com o intuito de "vencer" o pleito editara diversas medidas de caráter casuísta, porém a sociedade ratifica o MDB nos grande centros (sul e sudeste), colocando, portanto, em xeque o regime. Vendo-se extremamente desgatado o general presidente, Emílio Geisel, decide propor uma abertura lenta, segura e gradual. Para tanto, extingue o AI-5, em 1978.

No ano seguinte, assume o General João Figueiredo, disposto a dar continuidade a abertura política, porém sempre extremamente cioso de uma volta segura aos quarteis e com medo de uma revanche da esquerda, ou seja, abria o regime desde que não se julgassem os crimes da ditadura (tortura, prisões indevidas, mortes e desaparecidos políticos). Neste período é editado unilateralmente a Anistia, que propiciou a volta dos exilados e a liberdade

\footnotetext{
${ }^{9}$ Milagre econômico brasileiro é a denominação dada à época de excepcional crescimento econômico durante o Regime Militar no Brasil, entre 1968 e 1973, também conhecido pelos oposicionistas como "anos de chumbo". Nesse período do desenvolvimento brasileiro, a taxa de crescimento do PIB saltou de 9,8\% a.a. em 1968 para 14\% a.a em 1973, e a inflação passou de 19,46\% em 1968, para 34,55\% em 1974. Paradoxalmente, houve aumento da concentração de renda e da pobreza. Maiores informações ver in..: CORDEIRO, Janaina Martins. Anos de chumbo ou anos de ouro? A memória social sobre o governo Médici. Estud. históricos. vol.22 no.43 Rio de Janeiro Jan./June 2009.
} 
dos presos políticos; porém, obviamente, sem julgamento dos torturadores (FIGUEIREDO, 2009 e FIGUEIREDO, 2013). Esses marcos temporais são deveras importantíssimo e mostra o grande empenho da sociedade civil na luta pela Anistia e pela recuperação dos direitos civis e políticos, ainda destaca-se as grandes campanhas em favor da Anistia capitaneado pela classe artística como figura de proa no processo, tanto arrecando dinheiro para arrumar advogados para os presos políticos, quanto visitando-os pessoalmente nos presídios.

\section{TEATRO DA DENÚNCIA: DA ABERTURA E O ACERTO DE CONTAS POSSÍVEL}

Neste climax de abertura precisamos colocar em tela que se vivia a primeira fase da abertura política no Brasil. Em seu artigo acerca da transição democrática brasileira Maria D`Alva Kinzo, A democratização Brasileira: um balanço do processo político desde a transição (2001), sugere a divisão: Primeira Fase (1974 a 1982), na qual temos como fato marcante, já sublinhado neste artigo, o resultado da eleição de 1974, indo até a eleição de 1982; Segunda Fase (1982 a 1985), na qual é importante destacarmos a eleição de 1982 e a passagem do governo militar para um civil eleito pelo Colégio Eleitoral; finalmente, uma Terceira Fase (1985 a 1990), a partir do início do governo civil até a primeira eleição direta para presidente, que tomou posse em 1990. Essas três fases delimitadas por Kinzo são de grande valia para compreender o processo de transição; no tocante especificamente para situarmos temporalmente, nos dedicaremos especificamente na passagem da Primeira Fase para a Segunda Fase e os seus respectivos desdobramentos na cena teatral brasileira e na classe artística.

Ainda, realçamos sempre a conjugação e o enlace da classe artística com a cena política nacional, dessa forma registramos o nascimento dos primeiros partidos políticos pósAI-5, bem como a volta do multipartidarismo e a criação do Partido dos Trabalhadores (PT). Tais aspectos tornam-se importante uma vez que muitos personagens da classe artísticas engajados nos anos 60 e 70 assinaram ficha de filiação quando do lançamento do PT, como foi o caso da atriz e ex-presa política Bete Mendes, assim como, a consagrada atriz Lélia Abramo, que participou da montagem de Eles não usam Black Tie, em 1958; e, que assumiu a presidência do Sindicato dos Artistas e Técnicos em Espetáculos de Diversões do Estado de São Paulo, a partir de 1978. Ou seja, o PT galvanizou um conjunto de artistas, intelectuais, 
assim como, os sindicalistas do $\mathrm{ABC}$ na sua hoste com o intuito de construir um partido da classe trabalhadora e romper com os liames da ditadura militar (KECK, 1991; MENEGHELLO, 1989).

Torna-se importante enfatizar, conforme registrado por Kinzo, que ainda estávamos na primeira fase da transição do regime militar, que mesmo não tendo medidas tão restritivas e de arbítrios intenso; de qualquer modo, ainda havia sérios dissabores pela população, como por exemplo, o processo eleitoral de 1982 permeado por inúmeras medidas casuístas com o intuito de premiar com a vitória no pleito a ditadura militar (FERREIRA, 1991). Tal conjunto de ações fazia com que o povo organizado fizesse protesto contra a ditadura militar e transformassem as eleições em campanhas plebiscitárias para acabar de vez com a ditadura. Ou seja, seria o período do crepúsculo a ditadura militar e a classe artística continuava empunhando a bandeira de denúncia e de luta, era o momento agora de poder falar o que aconteceu, assim como, dos amigos e colegas de profissão que partiram para nunca mais voltar, como por exemplo, a peça escrita e dirigida por Jô Soares e encenada por Marcos Nanini, Brasil da Censura à Aberta (1980/1981), que como o próprio nome diz, visava passar a limpo o período tratado.

Ainda, é relevante destacar que as produções de peças de cunho denuncista se multiplicavam pelo Brasil, pois esta era a tônica do período. Destacamos um caso regional, no Rio Grande do Sul, o sucesso da peça Bailei na Curva (1983), que tinha como argumento justamente o percurso dos anos de chumbo até a transição democrática sobre o olhar das crianças que cresceram ao longo da ditadura militar e que sofreram o arbítrio. Tendo em seu conteúdo até mesmo denúncia de desaparecidos políticos - em síntese: A peça mostrava a trajetória de sete crianças, vizinhas da mesma rua na cidade de Porto Alegre, durante três décadas. Tem como pano de fundo os fatos políticos a partir do golpe militar de abril de 1964 até o movimento das Diretas Já, em 1984.

Quanto ao tempo político é importante compreendermos que nesta fase os novos personagens que emergiram neste cenário político e cultural no final da década de 70 não foram personagens isolados, mas sim parte integrante de um longo processo de luta no combate à ditadura, assim como "resultante da ideologia política pós-68” (CARDOSO, 1991, p.197). Ou seja, era o período do acerto de contas possível uma vez que a ditadura, mesmo cambaleando, ainda se mantinha e tentava de todas as formas não perder as regras do jogo no modelo de transição brasileira denominada de Transição pela Transação, (SHARE \& MAINWARING, 1986). Segundo esses autores, no caso de Transição pela Transação devemos considerar o fato de que são as elites autoritárias que "regulam o ritmo das reformas a serem 
implementadas, numa tentativa de resguardar-se contra a perda de controle. Mesmo que possam estar comprometidas com o restabelecimento da democracia, elas acreditam que é necessário realizar reformas de maneira gradual" (IDEM, p.209).

No tocante a classe artística o seu discurso conforme enfatizado se multiplicava tanto na denúncia contra a ditadura do que ocorreu, assim como, no engajamento em partidos políticos de esquerda emergente (PT), por exemplo, a atriz Bete Mendes se elege deputada federal pelo PT nas eleições de 1982. Ainda, contrastamos que começava a surgir fortemente a indústria cultural de massa no Brasil (ORTIZ, 1988), bem como, a consolidação, de fato, da televisão no Brasil com novelas que drenava muito dos atores de teatro para a seara televisiva tirando-os da ribalta, inclusive muitos diretores do CPC e do Arena estavam contratados da Rede Globo de Televisão, a maior empresa de comunicação do período recente do Brasil (RIDENTI, 2000). Não obstante, novos e velhos personagens (atores e diretores), se misturavam tanto no antigo palco do teatro quanto nas novelas; sendo que, embora se multiplicassem o lócus de trabalho e se efetivasse um espaço glamurizado para o exercício da profissão, percebemos resíduos da manutenção do discurso de esquerda na classe artística ainda no início dos anos 80 (IDEM, 2000).

Também, devemos destacar que esse momento foi o período, conforme realçado, do ajuste de contas possível, assim como, o período para curar o trauma do período ditatorial que se estava acabando. É neste período que consideramos que começa a se esboçar mais explicitamente a noção de "vítima da ditadura" (AYDOS \& FIGUEIREDO, 2013). Esta expressão constrói-se no período de redemocratização da virada dos anos 70 e ao longo dos anos 80 (SARTI, 2011). Também, destacamos que a noção de vítima se dá pela alteridade, pelo caráter contrastivos entre os que entraram para a luta, perderam e sofreram e os que ficaram na vida legalizada podendo tocar a sua vida e carreira ${ }^{10}$. Ou seja, as artes capturam essa catarse coletiva de poder falar sobre o que aconteceu e começou a haver peças que retratassem o período, bem como, as dores e angústia dos anos de arbítrio. Tais encenações foram reflexos da profusão da bibliografia de resistência, com o depoimento de inúmeros ex-

\footnotetext{
${ }^{10}$ Cynthia Sarti (2011, p. 54-55): “[...] a noção contemporânea de vítima adquire um novo estatuto a partir da definição, pela Psiquiatria, da categoria diagnóstica do Transtorno de Estresse Pós-Traumático (TEPT), com as formas terapêuticas que dela derivam. Resultante da orientação geral do DSM-III (a terceira versão do Diagnostic and Statistical Manual of Mental Disorders), publicado pela American Psychiatric Association em 1980, essa categoria diagnóstica constitui um dos suportes do tratamento das vítimas de violência na área da saúde mental na atualidade, constituindo-se em um importante articulador ideológico da produção da noção de vítima de violência no mundo contemporâneo".
} 
presos políticos que fizeram uso dos livros autobiográficos como forma de "elaboração"11 de tudo o que ocorreu (SILVA, 2008).

De certa forma, tínhamos nesse período o "velho" teatro com as suas grandes damas, bem como, o não tão novo teatro dos grupos coletivos da contracultura dos anos 70; ao mesmo tempo, tínhamos a massificada indústria cultural da televisão drenando os melhores da classe artística - mas um teatro de cunho social ainda se mantinha. Podemos dizer que a década de oitenta foi o último elo de manutenção de laço de coletividade que houve no teatro enfeixado pela "áurea” da esquerda, enquanto ainda vivia-se o crepúsculo a ditadura militar. Também, realçamos que antes o palco do teatro era o interlocutor quase que natural para se burlar a ditadura para dar voz para o povo falar, agora, existia outros mecanismos de comunicações que se multiplicavam e o teatro passava a ser um objeto distante demais da coletividade, pois era absorvido neste momento pela mídia televisiva.

Também, no mesmo período na década de 80 emergia um novo teatro, o denominado teatro besteirol, que eu cerne era um movimento teatral que nasceu em São Paulo, ganhando força no Rio de Janeiro na década de 80. Desprovido de preconceitos, o Besteirol incorporou diversas referências da cultura brasileira para montar uma caricatura do comportamento cotidiano. O humor anárquico e o rompimento com o engajamento e a cultura dita erudita forma os pilares do movimento. Em média com duração de noventa minutos, segundo Cleise Mendes (2009, p. 1) “a montagem reunia textos de Miguel Falabella (Avenida Pôr-do-Sol e A Sauna), Mauro Rasi (A Vedete Que Não Era Leviana e Uirapuancy) e Vicente Pereira (Detetive Santos), três dos principais autores que mantiveram o interesse do público por essa linha de teatro cômico”. Neste conjunto que emergia podemos considerar que as proximidades com a esquerda, partidos políticos começavam a ser rompidos através de novos personagens, novos atores e novas formas de se expressar; e, nesse sentido, ao mesmo tempo em que a ditadura perdia a sua força, também, um discurso mais esquerdizante refluía pela emergência de um novo paradigma de teatro que emergia (Besteirol).

Em 1984 houve o último grande ato contra a ditadura militar através da campanha das Diretas Já: que fora uma série de manifestação de massa contra o regime militar clamando por eleição direta. Foi um dos últimos apoios em massa da classe artística, pois esta se organizou e novamente foi às ruas clamar junto ao povo em grandes manifestações nas grandes cidades do país; porém novamente com insucesso. Segundo Ridenti (2000, p. 351) "a campanha foi derrotada no Congresso Nacional, que manteve as eleições indiretas. Esse

11 Utilizamos aqui o termo psicanalítico de "elaboração", ou seja, a ideia de que ao falar, escrever, narrar o evento traumático, os sujeitos atribuem significado a sua experiência e conseguem se não curar, conseguir ve sentido em suas vidas. 
resultado decepcionou a maioria dos brasileiros, inclusive os artistas que se enfronharam na campanha"; ou seja, foi o canto dos cisnes da classe artística no ambiente político. Em 1985, houve a passagem da ditadura militar para um governo civil, mas conforme Kinzo (2001) seria a terceira e última fase do processo transição, a ditadura terminava com severas seqüelas para as instituições brasileiras tanto no tocante a política, quanto para a educação e cultura ${ }^{12}$. Assim sendo, o Brasil ficou 21 anos sobre o arbítrio militar em que houve severos casos de abusos contra dos direitos humanos, neste cenário a cultura fora uma peça de resistência importantíssimo sendo o teatro um dos expoentes desse processo, pois o palco tornou-se um palanque político natural para denunciar os arbítrios da corporação militar.

\title{
5. CONCLUSÃO
}

\begin{abstract}
Na maior parte das vezes, lembrar não é reviver, mas refazer, reconstruir, repensar, com imagens e idéias de hoje, as experiências do passado. A memória não é sonho, é trabalho. Se assim é, deve-se duvidar da sobrevivência do passado, "tal como foi", e que se daria o inconsciente de cada sujeito. A lembrança é uma imagem construída pelos materiais que estão, agora, à nossa disposição, no conjunto de representações que representam nossa consciência atual. Por mais nítida que nos pareça a lembrança de um fato antigo, ela não é a mesma imagem que experimentamos na infância, por que nós não somos os mesmos de então e por que nossa percepção alterou-se e, com ela, nossas idéias, nossos juízos de realidade e de valores (...) (BOSI, 1994, p.55)
\end{abstract}

O Brasil no período de 21 anos foi confrontado pelo severo arbítrio da ditadura militar que promoveu um forte cerceamento institucional. Durante esete período a sociedade se oganizou para o seu conbtae, tanto no aspecto partidário e instiucional, quanto no aspecto cultural e artítisco. Em síntese, a classe artísitca e mais especificamente o grande "teatrão" foram personagens de proa desse processo de tentativa de rompimento do status quo ditatorial.

\footnotetext{
12 Segundo Marcelo Ridenti (2000, p. 351): “Já em 1989, os artistas participam ativamente nas primeiras eleições diretas presidenciais. Eles estiveram nas campanhas de todos os candidatos mais significativos, que evidentemente buscavam a transferência da popularidade dos artistas, esperando que ela se convertesse em votos. Os artistas eram convocados também a fim de atrair público para comícios e para programas eleitorais nos meios de comunicação. Isso vale para todos os candidatos, inclusive os de direita, que em geral pagavam cachês elevados para contar com a presença de artistas em suas aparições públicas. Mas o que interessa aqui é destacar a presença voluntária e gratuita de artistas engajados nas campanhas, em geral apoiando candidaturas que genericamente podem ser consideradas de esquerda, já se tratava de apoios individuais, e vários artistas, porém isolados, sem construir sequer um esboço de projeto alternativo à indústria cultural, como chegou a ocorrer nos anos 60 e um pouco ainda nos anos 70 e inícios dos 80 ".
} 
De acordo com o texto, realçamos que a classe artística através do palco soube fazer uso político de seu espaço: 1) num primeiro momento, resistindo e se organizando; 2) num segundo momento, mesmo sob coação partindo para o confronto armado; e, 3) numa terceira fase, servindo como elemento de denuncia e memória para contar as mazelas do que uma ditadura torcionária causou ao Brasil. Concluindo, vemos que a participação política da classe artística refluiu ao mesmo tempo que se consolidou a insdustria cultural televisiva; e, igualmente, decaiu o paradigma marxista na seara cultural ao longo da década de 80 .

Não obstante, enquanto marco temporal fica registrada a importância as peças de teatros e suas grandes damas, bem como, os grandes diretores e atores que conseguiram capturar ao seu modo a realidade brasileira; o quais tentavam modificar a realidade vivida buscando um projeto no campo do ideal, ou seja, um porvir futuro: democrático e socialista. Finalizando, embora este projeto de homem novo não tenha vicejado e se institucionalizasse, de fato, o que se consolidou foi a marca da genialidade desses personagens e a memória de um passado a ser relembrado: a memória do teatro contra a ditadura militar - feito de resistências e sonhos.

\section{REFERÊNCIAS}

AARÃO REIS FILHO, D. 1990. A revolução faltou ao encontro: os comunistas no Brasil. São Paulo: Ed. Brasiliense.

ARAÚJO, P. C. 2003. Eu não sou cachorro, não: música popular cafona e ditadura militar. 4. ed. Rio de Janeiro: Record.

AUTRAN, M. (S/D) Ofício de mãe. A saga de mulher. Rio de Janeiro: Ed. Marco.

AYDOS, V \& Figueiredo, C. A. S. 2013. A construção social das vítimas da ditadura militar e a sua ressignificação política. Revista Interseções. Rio de Janeiro, V. 15, n2, p. 392-314.

BOSI, E. 1994. Memória e sociedade: lembranças dos velhos. São Paulo: Cia das Letras.

CARDOSO, R. 1991. Sociedade em Movimento: novos atores dialogam com o Estado. In.: Revista Crítica de Ciências Sociais. N. 32.p. 129-34. Junho.

CARVALHO, L. M. 1998. Mulheres que foram à luta armada. São Paulo: Globo.

CORDEIRO, J. M. 2009. Anos de chumbo ou anos de ouro? A memória social sobre o governo Médici. Estud. históricos. vol.22 no. 43 Rio de Janeiro, p. 85-104.

DREIFUSS, R. 1964. 1981. A conquista do Estado: ação, política e golpe de classe. Petrópolis: Ed. Vozes. 
FERREIRA, D. 1991. Oposição e transição democrática: a estratégia peemedebista nas eleições de 1982. Dissertação de Mestrado PPGCP. Porto Alegre: UFRGS.

FIGUEIREDO, A. 1993. Democracia ou reformas?: alternativas democráticas à crise política: 19641964. São Paulo: Paz e Terra.

FIGUEIREDO, C. A. S. 2009. A relação dos PC's com o MDB-PMDB no cenário da transição e as eleições de 1982 no RS. Dissertação de Mestrado em Ciência Política, Universidade Federal do Rio Grande do Sul.

C. A. S. 2013. O Impacto da crise do socialismo nos partidos comunistas no Brasil. Tese de Doutorado em Ciências Políticas. Universidade Federal do Rio Grande do Sul.

GORENDER, J. 1987. Combate nas Trevas. A esquerda brasileira: Das ilusões perdidas à Luta Armada. São Paulo: Editora Ática.

KECK, Margaret. 1991. PT: a lógica da diferença: São Paulo. Ática.

KINZO, M. D. G. 2001. A democratização brasileira: um balanço do processo político desde a transição. Revista São Paulo em Perspectiva. 14 (4), p. 1-12.

MENEGUELLO, R. 1989. PT: a formação de um partido (1979-1982). Rio de Janeiro: Paz e terra, 1989.

ORTIZ, R. 1998. A moderna tradição brasileira: cultura brasileira e indústria cultural. São Paulo: Brasiliense.

PATARRA, J. 1992. Iara: reportagem biográfica. São Paulo: Rosa dos Ventos.

PATRIOTA, R. 1999. Vianinha: um dramaturgo no coração de seu tempo. São Paulo, Hucitec.

RIDENTI, M. 2000. Em busca do povo brasileiro: artistas da revolução, do CPC à era da TV. Rio de Janeiro, Editora Record.

SADER, Emir. 1991. Cuba no Brasil: Influências da revolução cubana na esquerda brasileira. In.: História do Marxismo no Brasil. V 1. O Impacto das Revoluções. (Org) AARÃO REIS FILHO, Daniel. Rio de Janeiro: Ed. Paz e Terra.

SARTI. C. 2011. A vítima como figura contemporânea. Caderno CRH (UFBA. Impresso), v. 24, 2011.

SHARE, D. \& MAINWARING, S. 1986. Transição pela transação: a democratização no Brasil e na Espanha. In.: Revista Dados. Rio de Janeiro. V. 29. N 2. p. 207-236.

SILVA, M. A. M. 2008. Os Escritores da Guerrilha Urbana: Literatura de Testemunho, Ambivalência e Transição Política (1977-1984). São Paulo: Annablume/ Fapesp. 
SIRKIS, Alfredo. 1984. Os carbonarios: memórias da guerrilha perdida. 9. ed. São Paulo: Global.

VENTURA, Z. 1988. 1968: o ano que não terminou. 18. ed. Rio de Janeiro: Nova Fronteira.

\section{INTERNET}

MENDES, C. F. 2009. O teatro, a besteira e a cultura da crítica. V ENECULT- Encontro de Estudos Multidisciplinares em Cultura. Salvador. Disponível em: http://www.cult.ufba.br/enecult2009/19242-4.pdf. Acessado em 04/07/2014.

\section{VÍDEO CITADO}

${ }^{1}$ Dži Croquete. 2009. In.: http://www.youtube.com/watch?v=rgy8fXEqw98. Assistido em 04/07/2014. 